DOI

\title{
ІННОВАЦІЙНІ МЕТОДИ ПРОВЕДЕННЯ СЕМІНАРСЬКИХ ЗАНЯТЬ В ІНОЗЕМНИХ СТУДЕНТІВ ПРИ ВИВЧЕННІ АКУШЕРСТВА ТА ГІНЕКОЛОГІї
}

\author{
І. В. Корда, С. М. Геряк, Н. І. Багній, О. Є. Стельмах, І. Я. Кузів, Н. В. Петренко \\ ДВНЗ “Тернопільський державний медичний університет імені I. Я. Горбачевського \\ МОЗ України”
}

\section{INNOVATIVE METHODS OF SEMINARS TO FOREIGN STUDENTS IN THE STUDYING OF OBSTETRICS AND GYNECOLOGY}

\author{
I. V. Korda, S. M. Heryak, N. I. Bahniy, O. Ye. Stelmakh, I. Ya. Kuziv, N. V. Petrenko \\ SHEI “Ternopil State Medical University by I. Ya. Horbachevsky \\ of MPH of Ukraine"
}

\begin{abstract}
У статті наведено досвід використання рольової гри при проведенні семінарських занять як одного з інноваційних методів навчання іноземних студентів-медиків.

The article presents the experience of using the role-play during the seminars as one of the innovative method of teaching of foreign medical students.
\end{abstract}

Вступ. У сучасній медичній освіті існує багато різноманітних форм та методів інноваційного навчання, спрямованих на якісне засвоєння знань студентами-медиками, розвиток їх розумової діяльності, виявлення умінь та навичок критичного осмислення проблем, набуття досвіду самостійного опрацювання навчального матеріалу, пошукової роботи, набуття якостей, які стануть у нагоді в подальшому розвитку самоосвіти і самореалізації. Однією із таких форм є семінарські заняття, які забезпечують розвиток творчого професійного мислення, пізнавальної мотивації і професійного використання в майбутній професії.

Основна частина. Традиційні семінари - один з поширених видів занять у вищих навчальних закладах. Семінар є засобом розвитку у студентів культури наукового мислення, а також призначений для поглибленого вивчення дисципліни, оволодіння методикою наукового пізнання.

Мета семінару полягає в тому, щоб знання, які отримали студенти, наприклад, на лекції або в результаті самостійної роботи, розширилися, поглибилися, закріпилися, набули якісно нового змісту. Студенти на семінарах навчаються бути здатними до самостійних суджень, відтворення

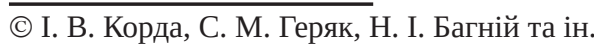

та поглиблення знань. Семінарське заняття являє собою групове заняття, яке проводиться під керівництвом викладача, як правило, після самостійної підготовки студентів групи. Викладач організовує дискусію навколо попередньо визначеної теми, до якої студенти готують реферати, виступи на підставі індивідуально виконаних завдань. Основні завдання семінарського заняття: розвиток пізнавальної активності і самодіяльності студентів, уміння застосовувати матеріал лекцій, поглиблення i закріплення знань, отриманих у процесі вивчення предмета, сприяння розвитку логічного мислення, формування вміння логічно висловлювати і аргументувати свої думки та слухати один одного, продуктивне критикування.

Семінарські заняття виступають також засобом перевірки розвитку і закріплення навичок самостійної роботи, що є однією з найважливіших форм навчальної роботи студентів та сприяють вихованню ініціативи, активності, самостійності в роботі, привчають до систематичного, планомірного засвоєння навчального матеріалу, монографічної та іншої літератури, медичних протоколів. Успіх семінарських занять у вищих навчальних закладах значною мірою залежить від їх раціональної організації та активних методів проведення: тематичні дискусії та диспути, колективний пошук відповідей, бесіда 
і вільний обмін думками; інформація про конструктивні пропозиції студентів, ігрове проектування.

Крім організаційних моментів, важливу роль відіграє методика проведення семінарських занять. Основними методами проведення є спільна робота викладача (вступне і заключне слово) і студентів, а також бесіда, ілюстрації і демонстрації. Звичайно, всі вони використовуються не ізольовано, а в поєднанні. Не існує жодного семінарського заняття, яке б проводилось за однією методикою. Основною складовою частиною більшості семінарських занять $є$ виступи студентів, після яких розгортається бесіда, в якій бере участь як доповідач, так і викладач чи інші студенти. Головною метою цього $є$ максимальна активізація мислення студентів, перетворення семінару з механічного викладення фактичного матеріалу в динамічний, цікавий пізнавальний процес.

Однією із частин інноваційного навчання на семінарі є групова та індивідуальна форма роботи. Акцент зміщений на творчу імпровізацію студента, на його взаємодію із викладачем. Довіра, повага, спілкування, стимуляція почуття гідності, здатності відповідати за себе є головним фактором групової та індивідуальної форм роботи. Студент розвиває свою індивідуальність у спільному вирішенні творчих завдань, коли залучається його життєвий досвід і отримані знання.

Іншим пріоритетом $є$ диференціація навчання, коли урізноманітнюються форми і методи навчальної діяльності, коли опорою стає уміння студентів самостійно здобувати знання. Самооцінка студентів перетворюється на головний фактор оцінювання особистих досягнень. Навчання, таким чином, перетворюється на спілкування між людьми в отриманні нової інформації. Викладач має стати посередником між студентом і навчальним матеріалом, а не єдиним джерелом знань.

Отже, виходячи з цієї нової ролі, викладач повинен використовувати різноманітні методи подачі нового матеріалу, ставити завдання, які дозволяють студентам засвоїти навчальний матеріал відповідно до рівня їх підготовки та можливостей пізнавальної діяльності, надати можливість студентам демонструвати свої досягнення в отриманні знань.

Дуже важливою є спільна робота студентів у великих і малих групах. Ця методика пропонує зміну традиційної обстановки на семінарських заняттях. Роль викладача змінюється з традиційної на посередницьку. Головним стає колективне знання групи, допомога у з’ясуванні окремих питань, обговорення підготовлених презентацій, рефератів. Академічна група розділяється на 2-3 підгрупи по 4-6 студентів.

Розмір такої підгрупи залежить від кількості студентів в академічній групі, доступності джерел і змісту завдання. Така організація роботи сприяє залученню всіх студентів з урахуванням рівня їх розвитку освоєння матеріалу та можливостей сприйняття матеріалу. Особливе значення набуває при цьому диференційний підхід до визначення завдань. Обговорення в підгрупі дозволяє: заохочувати студентів до діалогу; залучати до обговорення проблем без будь-яких обмежень; вирішувати проблеми, які викликають загальний інтерес; шукати згоди в суперечливих ситуаціях; обмінюватися думками, порівнювати протилежні позиції.

Студенти внаслідок групової роботи набувають певних навичок: навчаються брати на себе відповідальність за спільну та індивідуальну підготовку, відстоювати свою позицію, співпрацювати, обмінюватися інформацією, виконувати різні ролі та брати на себе відповідальність (роль лідера чи підлеглого). Завдання викладача при груповій роботі: правильно сформулювати завдання та забезпечити взаємодію підгруп; підготувати цікавий заохочувальний матеріал, бути партнером, вносити корективи, направляти роботу підгруп.

На семінарі можна розглянути кілька проблем. Їх всі необхідно розв’язувати в групах. Але неодмінною умовою є формулювання проблеми та робота з нею в групах, прийняття узгодженого рішення і діалог за підсумками роботи. Діалог - це співробітництво учасників навчального процесу, з одного боку - різних груп студентів, з другого - студентів і викладача з метою спільного пошуку рішення. Тому воно направлено на пошук спільних знаменників, розширення і можливу зміну власного погляду, відвертість у взаємовідносинах. Як доводять дослідження, групові дискусії сприяють засвоєнню 50 \% матеріалу.

Дискусії як словесний обмін ідеями і думками з теми корисні тим, що дають можливість активізувати розумову діяльність студентів, уміння висловлювати власні думки, використовувати набуті знання.

Достатньо популярний засіб навчання у дискусії є так звана “Мозкова атака” Студентам пропонують якусь клінічну ситуаційну роботу, для їі вирішення пропонується якомога більше альтернативних засобів, які потім аналізуються самими студентами. 
До активних форм навчання, які сприяють засвоєнню до 70 \% матеріалу, відносяться і рольові ігри. Під час їх проведення розігруються клінічні випадки, які студентам не траплялися раніше. Кожна рольова гра може тривати декілька хвилин, за цей час студент має визначитись з попереднім діагнозом, планом обстеження та лікування або ж першої допомоги у разі невідкладних станів. Метою рольових ігор є допомога студентам у закріпленні знань та навичок у вільній сприятливій атмосфе-

\section{Список літератури}

1. Казаков В. М. Новітні тенденції розвитку європейської медичної освіти / В. М. Казаков, О. М. Талалаєнко, М. Б. Первак // Медична освіта. - 2009. - № 2. С. $40-44$.

2. Использование инновационных и интерактивных методов обучения при проведении лекционных и семинарских занятий / С. В. Базилевич, Т. Б. Брылова, В. Р. Глухих, Г. Г. Левкин // Наука Красноярья. - 2012. - № 4. - С. 103-113. pi. Рольові ігри можуть дати багатий матеріал для обговорення.

Важливе значення мають на семінарському занятті унаочнення та місце проведення, тому на цих аспектах акцентується особлива увага викладача.

Висновок. Таким чином, включення активних методів навчання (традиційний семінар, індивідуальна робота, робота в групах, діалог і дискусія) можуть зробити семінари з предмета “Акушерство та гінекологія” більш цікавими та ефективними.

3. Azer S. A. Twelve tips for creating trigger images for problem-based learning cases / S. A. Azer // Med. Teach. 2007. - Vol. 29 (2-3). - Р. 93-97.

4. Гнезділова К.М. Моделі та моделювання у професійній діяльності викладача вищої школи : навч. посіб. / К. М. Гнезділова, С. О. Касярум. - Черкаси : Вид. Чабаненко Ю.А., 2011. - 124 с.

5. http://www.nmu.edu.ua/files/strateg_rozv_2012.pdf

6. http://advan.physiology.org/content/37/1/106

Отримано 23.04.15 